\title{
Sexual Fluidity: An Integrative Review
}

\author{
Steve Hunt, BSN, MScN (cand.), LLB (cand.)
}

Faculty of Health, Laurentian University, Canada \&

Bora Laskin Faculty of Law, Lakehead University, Canada

Elena Hunt, PhD

Faculty of Health, Laurentian University, Canada

Doi:10.19044/esj.2018.v14n32p182 URL:http://dx.doi.org/10.19044/esj.2018.v14n32p182

\begin{abstract}
Historically, sexuality had been considered a fundamental, biologically determined characteristic of humans. Lately, better protection of human rights and recognition of non-traditional relationships have been leading to acceptance towards gay, transgendered and bisexual people. Nonetheless, little advancement has been made into fully understanding the intricacies of human sexuality and recent research has found that sexuality may not be fixed after all; instead, it appears to be more variable and fluid.

This integrative review on sexual fluidity has drawn four discussed themes: Sexuality as a Continuum, Sexual Fluidity of Women, Sexual Agency and Hetero/Homosexuality Binary of Men.

Several questions call for more research into understanding sexual fluidity across the lifespan and the development of initiatives to help individuals to both understand and accept this trait. Furthermore, advocacy is needed to ensure equal rights and freedoms without discrimination, both socially and economically.
\end{abstract}

Keywords: Sexual fluidity, sexual variability, sexuality, homosexual, heterosexual, continuum, hegemony.

For the longest time, sexuality had been considered a fundamental, biologically determined characteristic of humans. With the advancement of healthcare technology and with the protection of human rights and recognition of non-traditional relationships, more and more acceptance has been given to gay, transgendered and bisexual individuals (Weber, 2012). Although progress has been made in ensuring their legal rights are protected, little advancement has been made into fully understanding the intricacies of human sexuality.

The notion that human sexuality is biologically determined and fixed remains the predominant societal hegemony, but according to Ward (2015), inconclusive and mixed evidence supports this claim. Recent research has 
found that sexuality may not be fixed after all; instead, it appears to be more variable and fluid.

The notion of a "fluid" sexuality is not new. In fact, in the 1940s, in his pioneering work on human sexuality, Alfred Kinsey identified that sexuality exists on a continuum, with some people being predominantly heterosexual, some being predominantly homosexual and many existing in-between (Kinsey, Pomeroy \& Martin, 1948). Kinsey published two reports outlining this phenomenon, the first one being the Sexual Behaviour in the Human Male which was initially published in 1948 following Sexual Behaviour in the Human Female which was published in 1953.

Kinsey's work was further strengthened and rekindled with the work of Diamond, whose research led to the development of a theory of sexual fluidity. Diamond proposed this theory in the early 2000s, publishing a proposed bio-behavioural model of romantic love and physical desire (Diamond, 2003). Further, many studies emerged, exploring the concept of sexual fluidity and further augmenting what is known about human sexuality.

\section{Purpose}

The purpose of this integrative review is to explore what is known about the concept of sexual fluidity and its historic origins. It attempts to answer the following questions: 1) What is sexual fluidity and what are its inferences? 2) What are the origins of sexual fluidity? With this end in view, a critical overview of the available research and literature on the concept of sexual fluidity and how it relates to human sexuality will be presented.

\section{Framework}

This integrative review was guided by the framework proposed by Whittemore and Knalf (2005) where literature is collected, analyzed and critiqued, then discussed and presented in an organized fashion. However, due to the relative novelty of the topic and the immaturity of the available research, less emphasis is placed on the critique and exclusion of available data, in an effort to ensure inclusivity. All available knowledge on the topic is given equal consideration and is included fairly to further enhance what we contemporaneously know about sexual fluidity.

\section{Review Process and Outcomes}

In reviewing the literature, multiple keywords were used to retrieve articles, such as sexual fluidity, variability, situation and sexuality, and heteroflexibility. In addition, MESH headlines were searched for "sexual fluidity" but no similar words were found. Thus, the literature search was limited to the terms identified. 
EBSCO host was used to scan multiple databases including: PsychINFO, CINHAL, PROQUEST Nursing and Allied Health, PubMed/Medline, Francis, AgeLine, SPORTDiscus and Business Source Complete. In addition, Google Scholar was also used to retrieve any additional article outside of the identified databases.

Reference checking was also employed to further identify any other sources of information. Google Scholar led to the identification of key theorists/scholars within the domain of Sexual Fluidity, including Diamond, Ward, Anderson and Blank. These scholars were reviewed on either personal or academic affiliated websites. These websites were then searched for references to related works.

Inclusion criteria were: recent from 1990 and up (1990 chosen as it was an era that saw great advancement in human rights and acceptance of gender and sexual differences) ; primary research, philosophical/critical analysis or historical review of the topic. The exclusion criteria included: research outside of the North American context. The exclusion criteria was kept minimal to further enhance inclusivity.

Grey literature and scholarly works found through the review of key scholars/theorists' websites and their publications were also included. In addition, historic works such as the work by Kinsey and Humphrey were included, as identified in reference tracking of contemporary work, for their profound relevance to the emerging concept of sexual fluidity.

Three contemporary works (novels) by Blank (2012), Diamond (2009), and Ward (2015) were also included in the analysis. Furthermore, three historic works by Foucault (1984), Humphreys (1970) and Kinsey et al. (1948) were included and one presentation by Diamond (2013) was also included in this review.

After applying filters to the database search hosts, a total of 2,276 articles were retrieved. In total, including the grey literature, 21 articles and scholarly work were selected for inclusion in the present review.

\section{Results}

Of the 21-works retained for analysis, five used a qualitative design (Aramburu AlegrÍa, 2013; Coleman-Fountain, 2014; L. Diamond, 2009; Esterline \& Galupo, 2013; Humphreys, 1970), seven used a quantitative design (Diamond, 2013; Higgins, 2004; Katz-Wise \& Hyde, 2014; Katz-Wise, Reisner, Hughto, \& Keo-Meier, 2016; Mock \& Eibach, 2011; Ott, Corliss, Wypij, Rosario, \& Austin, 2010; Russell, Clarke, \& Clary, 2009), and eight are classified as "other", including three historical reviews (Blank, 2012; Brickell, 2006; Foucault, 1984), two social critiques (Fantus, 2013 \& Ward, 2015), one used a mixed design (Kinsey et al., 1948) and one was a presentation reporting on the emerging results of a quantitative study by Diamond (2013). 


\section{Summary of articles retained for analysis}

\begin{tabular}{|c|c|c|c|}
\hline Author & Method & Sample & Overview \\
\hline $\begin{array}{l}\text { Aramburu Alegría } \\
\text { (2013) }\end{array}$ & Qualitative - interviews & $\begin{array}{l}16 \text { females } \\
\text { partnered with } \\
\text { male-to-female } \\
\text { transgendered } \\
\text { partners }\end{array}$ & $\begin{array}{l}\text { Females maintained a heterosexual identity; } \\
\text { however, they were conflicted in their } \\
\text { understanding of their orientation. The author } \\
\text { identified } 4 \text { themes: } 1 \text { ) questioning of sexual } \\
\text { orientation; (2) sexual orientation } \\
\text { categorization; (3) relational fluidity without } \\
\text { sexual relations; and (4) relational fluidity } \\
\text { with sexual relations. }\end{array}$ \\
\hline $\begin{array}{l}\text { Katz-Wise, S. L. } \\
\text { \& Hyde, J. S. } \\
\text { (2014) }\end{array}$ & $\begin{array}{l}\text { Quantitative - online } \\
\text { questionnaire }\end{array}$ & $\begin{array}{l}188 \text { young } \\
\text { adults, males } \\
\text { and females }\end{array}$ & $\begin{array}{l}\text { 63\% of females and } 50 \% \text { of males reported } \\
\text { sexual fluidity in their attraction. } \\
\text { Females were more likely than males to } \\
\text { endorse sexual fluidity. }\end{array}$ \\
\hline $\begin{array}{l}\text { Katz-Wise, S. L., } \\
\text { Reisner, S. L., } \\
\text { Hughto, J. W. \& } \\
\text { Keo-Meier, C. L. } \\
\text { (2016) }\end{array}$ & $\begin{array}{l}\text { Quantitative - online } \\
\text { questionnaire/survey }\end{array}$ & 452 adults & $\begin{array}{l}58.2 \% \text { of participants reported having } \\
\text { changed their orientation at least once in their } \\
\text { lifetime. } \\
\text { Among individuals who transitioned gender, } \\
64.6 \% \text { reported a change in their attraction } \\
\text { post-transition. }\end{array}$ \\
\hline $\begin{array}{l}\text { Mock, S. E. \& } \\
\text { Eibach, R. P. } \\
\text { (2011) }\end{array}$ & $\begin{array}{l}\text { Quantitative - using } \\
\text { results from National } \\
\text { Survey on Midlife } \\
\text { Development in the } \\
\text { United States }\end{array}$ & $\begin{array}{l}2,560 \text { men and } \\
\text { women }\end{array}$ & $\begin{array}{l}\text { Heterosexuality was the most stable identity. } \\
\text { - } \\
\text { Among women, bisexuality and } \\
\text { homosexuality were equally unstable. } \\
\text { Among men, heterosexuality and } \\
\text { homosexuality were equally stable, while } \\
\text { bisexuality was unstable. }\end{array}$ \\
\hline $\begin{array}{l}\text { Notman, M. T. } \\
\text { (2002) }\end{array}$ & Critical analysis & NA & $\begin{array}{l}\text { Argues that during a woman's midlife, } \\
\text { personal identity and values change. Women } \\
\text { feel that they no longer need to conform. } \\
\text { Argues that fluidity of choice may be a } \\
\text { characteristic of women. }\end{array}$ \\
\hline Blank, H. (2012) & $\begin{array}{c}\text { Critical review of the } \\
\text { history of } \\
\text { heterosexuality }\end{array}$ & NA & $\begin{array}{l}\text { Argues that the term heterosexuality evolved } \\
\text { as a way for physicians to classify those who } \\
\text { engaged in too much intercourse and those } \\
\text { who engaged in intercourse that was not pro- } \\
\text { creative in nature. } \\
\text { As society evolved more descriptive terms } \\
\text { were conceived for deviant sexual } \\
\text { behaviours. } \\
\text { Eventually sexuality evolved to transcend the } \\
\text { antiquated terms still used currently. }\end{array}$ \\
\hline Diamond. (2013) & $\begin{array}{l}\text { Diamond presents her } \\
\text { ongoing findings of a } \\
\text { Quantitative study }\end{array}$ & TBD/NA & $\begin{array}{l}\text { Sexual fluidity is characteristic of both men } \\
\text { and women. } \\
\text { Sexual fluidity is more prevalent in children, } \\
\text { showing equal attraction to both, same and } \\
\text { opposite sex. } \\
\text { In addition to heterosexual men having sex } \\
\text { with men, homosexual men were also } \\
\text { identified to engage in heterosexual sex and } \\
\text { show attraction to women. }\end{array}$ \\
\hline $\begin{array}{l}\text { Diamond, L. } \\
\text { (2009) }\end{array}$ & Qualitative longitudinal & $\begin{array}{l}79 \text { lesbian, } \\
\text { bisexual or }\end{array}$ & $\begin{array}{l}\text { Many women experienced a change in their } \\
\text { orientation at one point in time. }\end{array}$ \\
\hline
\end{tabular}




\begin{tabular}{|c|c|c|c|}
\hline & & $\begin{array}{l}\text { unlabelled } \\
\text { women }\end{array}$ & $\begin{array}{l}\text { - Women identified contention in attempts to } \\
\text { label themselves as bisexual, heterosexual } \\
\text { and homosexual. } \\
\text { - Some women with a label of homosexual } \\
\text { would still engage in heterosexual behaviour } \\
\text { out of convenience. }\end{array}$ \\
\hline Diamond (2003) & $\begin{array}{c}\text { Framework proposal } \\
\text { based on qualitative } \\
\text { research }\end{array}$ & NA & $\begin{array}{l}\text { - } \\
\text { and attraction. } \\
\text { - } \quad \text { Argues that love and attraction are } \\
\text { bidirectional and many who engage in } \\
\text { intimate relationships with one gender may } \\
\text { still show love and affection to another } \\
\text { gender. }\end{array}$ \\
\hline $\begin{array}{l}\text { Brickell, C. } \\
\text { (2006) }\end{array}$ & $\begin{array}{l}\text { Critical review of } \\
\text { history }\end{array}$ & NA & 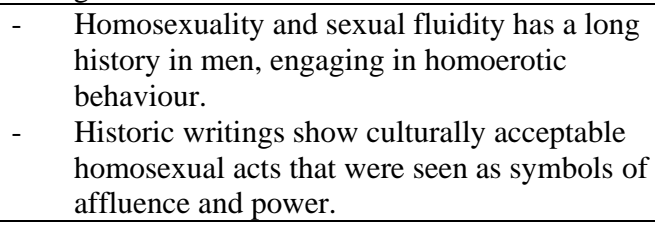 \\
\hline $\begin{array}{l}\text { Coleman- } \\
\text { Fountain, E. } \\
\quad(2014)\end{array}$ & Qualitative - interviews & $\begin{array}{l}19 \text { young } \\
\text { individuals } \\
\text { between } 16-21 \\
\text { years old }\end{array}$ & 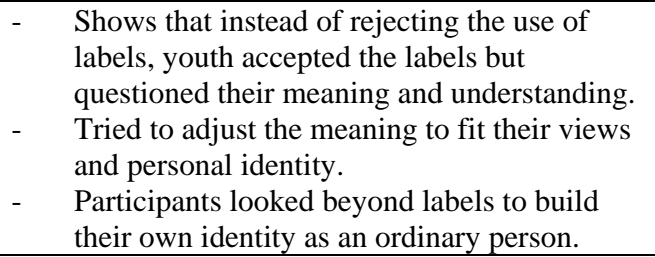 \\
\hline $\begin{array}{l}\text { Drummond, M. J. } \\
\text { N., Filiault, S. M., } \\
\text { Anderson, E. \& } \\
\text { Jeffries, D. (2014) }\end{array}$ & Qualitative - interviews & $\begin{array}{l}90 \text { heterosexual } \\
\text { men }\end{array}$ & $\begin{array}{l}\text { - } 29 \% \text { had engaged in a same sex kiss with } \\
\text { piers. } \\
\text { - } \\
\text { More acceptance of homosexuality among } \\
\text { heterosexual undergraduate men signifying a } \\
\text { cultural shift in acceptance. }\end{array}$ \\
\hline $\begin{array}{l}\text { Esterline, K. M. } \\
\text { \& Galupo, M. P. } \\
\text { (2013) }\end{array}$ & $\begin{array}{l}\text { Online survey - open } \\
\text { ended questions }\end{array}$ & $\begin{array}{l}219 \text { men and } \\
\text { women }\end{array}$ & 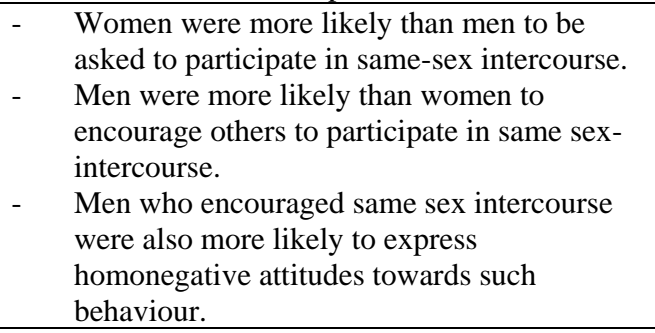 \\
\hline Fantus (2013) & Framework proposal & NA/case study & $\begin{array}{l}\text { - } \text { Social categories have been created in } \\
\text { attempts to elicit social control over groups of } \\
\text { individuals which have perpetuated } \\
\text { stereotypical attitudes towards gender and } \\
\text { sexual identity. } \\
\text { - Viewing sexuality as a dichotomy does not } \\
\text { permit people to question their identity and to } \\
\text { exist on a continuum that may not be } \\
\text { recognized as a socially acceptable or } \\
\text { identified categorization. }\end{array}$ \\
\hline $\begin{array}{l}\text { Foucault, M. } \\
\text { (1990) }\end{array}$ & $\begin{array}{l}\text { Critical review and } \\
\text { analysis of history and } \\
\text { philosophy of sexuality }\end{array}$ & NA & $\begin{array}{l}\text { - Argues that as society has advanced, we have } \\
\text { become more sexually repressed and } \\
\text { perverse. } \\
\text { Argues that sex and sexuality went from } \\
\text { being an art to a science and that sex can only } \\
\text { be discussed under the pretense of discourse, }\end{array}$ \\
\hline
\end{tabular}




\begin{tabular}{|c|c|c|c|}
\hline & & & $\begin{array}{l}\text { or academic works as opposed to } \\
\text { appreciating the art of sex. }\end{array}$ \\
\hline $\begin{array}{l}\text { Higgins, D. J. } \\
\text { (2004) }\end{array}$ & $\begin{array}{l}\text { Self report } \\
\text { questionnaire }\end{array}$ & $\begin{array}{l}69 \text { gay men }(26 \\
\text { of them were } \\
\text { previously } \\
\text { married to } \\
\text { women) }\end{array}$ & $\begin{array}{l}\text { No differences in terms of sexual identity, } \\
\text { homophobia or self-depreciation found } \\
\text { between those who were married and those } \\
\text { who were never married to a woman. } \\
\text { The results lead to further confusion as to the } \\
\text { motivating factors behind gay men marrying } \\
\text { women and highlights the need for more } \\
\text { research. }\end{array}$ \\
\hline $\begin{array}{l}\text { Humphreys, L. } \\
\text { (1970) }\end{array}$ & Qualitative & & $\begin{array}{l}\text { Men frequently would engage in impersonal } \\
\text { sexual encounters with other men as a way to } \\
\text { simply achieve sexual gratification without } \\
\text { any emotional involvement. }\end{array}$ \\
\hline $\begin{array}{l}\text { Kinsey, A. C., } \\
\text { Pomeroy, W. R. } \\
\text { \& Martin, C. E. } \\
\quad(1948)\end{array}$ & Mixed & $\begin{array}{l}5300 \text { males and } \\
5940 \text { female }\end{array}$ & $\begin{array}{l}\text { - } \begin{array}{l}\text { Proposes sexuality as a continuum and } \\
\text { developed the Kinsey scale. }\end{array} \\
37 \% \text { of males and } 13 \% \text { of females had at } \\
\text { least one homosexual experience leading to } \\
\text { orgasm in their lifetime. } \\
\text { - } 10 \% \text { of males were "predominately } \\
\text { homosexual". } \\
\text { - } \% \text { of males were "exclusively homosexual" } \\
\text { - } \\
2 \% \text { to } 6 \% \text { of females were more or less } \\
\text { exclusively homosexual. }\end{array}$ \\
\hline $\begin{array}{l}\text { Ott, M. Q., } \\
\text { Corliss, H. L., } \\
\text { Wypij, D., } \\
\text { Rosario, M., \& } \\
\text { Austin, S. B. } \\
\text { (2010) }\end{array}$ & Quantitative & 13,840 youth & $\begin{array}{l}\text { - } 10 \% \text { of males and } 20 \% \text { of females described } \\
\text { themselves as a sexual minority at one point. } \\
2 \% \text { of both males and females reported ever } \\
\text { being "unsure" of their sexual orientation. } \\
\text { - Females reported significantly higher sexual } \\
\text { mobility than males. } \\
\text { - Sexual minorities had higher mobility scores } \\
\text { than the full cohort. No gender difference } \\
\text { when considering the full cohort. }\end{array}$ \\
\hline $\begin{array}{l}\text { Russell, S. T., } \\
\text { Clarke, T. J. \& } \\
\text { Clary, J. (2009) }\end{array}$ & Survey & $\begin{array}{c}2,560 \\
\text { adolescent } \\
\text { youth }\end{array}$ & $\begin{array}{l}\text { Typical sexual identity labels are endorsed by } \\
71 \% \text { of non-heterosexual youth. } \\
\text { - } 13 \% \text { reported that they were questioning their } \\
\text { sexual identities. } \\
\text { 9\% provided alternative labels to describe } \\
\text { their identity. }\end{array}$ \\
\hline Ward, J. (2015) & $\begin{array}{l}\text { Critical Social } \\
\text { Review/Included review } \\
\text { of Qualitative Content } \\
\text { of Personal Ads }\end{array}$ & NA & $\begin{array}{l}\text { Men frequently engage in homoerotic } \\
\text { behaviour as a rite of passage into manhood, } \\
\text { especially in masculine social instructions } \\
\text { such as fraternities and militaries. } \\
\text { Men engage in homoerotic behaviour as a } \\
\text { social requirement to attain heteronormative } \\
\text { standards (i.e. fraternity hazing). } \\
\text { Heterosexual men also seek out homoerotic } \\
\text { situations with men in an attempt to bond and } \\
\text { re-live their youth. }\end{array}$ \\
\hline
\end{tabular}

\section{Analysis}

In alignment with the integrative review framework proposed by Whittemore and Knafl (2005), a thematic analysis was employed to organize 
the available research. From the selected literature, 4 themes emerged: sexuality as a continuum, sexual agency, sexual fluidity of women and the hetero/homosexual binary of men. The results are presented as follows.

\section{Sexuality as a continuum}

The idea of sexuality as a continuum is not new. It was first proposed in Kinsey and colleagues' report on the sexual behaviour of the human male, initially published in 1948 (Kinsey et al., 1948). Kinsey and colleagues argued that sexuality fit more into a continuum than a fixed human trait, finding much variability within the sexual behaviour of men. In fact, according to Kinsey et al. (1948), up to $46 \%$ of men had experienced some sexual arousal to both same and opposite sex at one point in their life and up to $37 \%$ had at least one homosexual encounter in their life. Based on these results, Kinsey and colleagues developed the Kinsey scale to operationalize sexuality and place individuals on a continuum, with participants sexual orientation ranging from 0 (completely heterosexual) to 6 (completely homosexual).

Diamond (2009) built on this idea in her 10 year, qualitative longitudinal study on women, finding sexual variability amongst all her participants during at least 1 point in time. While Diamond (2009) and Kinsey et al. (1948) identify a sexuality continuum, the degree of stability is variable and remains in question, with Diamond reporting more variability among women than Kinsey et al. (1948) proposes in men.

These outcomes compliment the research by Mock and Eibach (2011) who found that those identified as heterosexual tend to have a more stable sexual identity. Furthermore, women tend to have more unstable identities when compared to men (Mock \& Eibach, 2011). This characteristic will be discussed further under the next theme.

\section{Sexual Fluidity of Women}

Several studies discuss the fluidity of sexuality in women (Aramburu AlegrÍa, 2013; Diamond, 2013; L. Diamond, 2009; L. M. Diamond, 2003; Katz-Wise \& Hyde, 2014; Katz-Wise et al., 2016; Mock \& Eibach, 2011; Notman, 2002; Ott et al., 2010). The concept gained momentum with the work of Diamond (2009) and her proposal for a new model of sexual fluidity in women. Diamond (2003) also developed a model of bio-behavioural sexual desire and attraction which, again, relied heavily on her research with women.

With Diamond's work highlighting the possibility of such a model, research has begun to accumulate exploring this phenomenon further and showing that variability is high among women and their sexual identity (Diamond, 2009; Notman, 2002); however, in the study by Aramburu AlegrÍa (2013) investigating women partnered with male-to-female transgender, while they were seen as same-sex partners, females maintained a heterosexual 
identity but questioned their own sexual identity and were conflicted about their orientation. This highlights the idea of labels of sexual identity and how men and women attempt to fit into these preconceived ideas of sexual orientation.

\section{Sexual Agency}

Sexual Agency refers to the complex inter-play of history, cultural and societal hegemony, as they relate to sexuality and sexual identity. The theme of sexual agency was inter-woven in every article included in this review and is arguably the most complex and significant theme as it pertains to understanding the concept of sexual fluidity.

Some of the studies identified internal contention when individuals attempted to identify their sexual orientation (Esterline \& Galupo, 2013; KatzWise \& Hyde, 2014; Russell et al., 2009). Diamond (2009) identifies the confusion and apprehension experienced by some of the participants when attempting to self-label their sexual orientation, resulting from complex experiences of attraction to both the same and opposite sex. While bisexuality has traditionally been the term of favour for those who experience attraction to both the same and opposite sex, the available research shows that bisexuality is among one of the most unstable identities, showing the most variation in sexual attraction over time (Diamond, 2009; Katz-Wise et al., 2016; Mock \& Eibach, 2011; Notman, 2002).

In fact, in the study of Russell et al. (2009) $9 \%$ of adolescents $(\mathrm{N}=2,560$ secondary school students in California) used their own labels to identify their sexual orientation that expressed ambivalence and/or fluidity in their orientation. This self-labeling was also identified amongst participants in the longitudinal study by Diamond (2009). Considering the adolescents in her presentation, Diamond discusses the fluidity of children and how children, both boys and girls, tend to have equal degrees of attraction for both the same and opposite sexes (Diamond, 2013). However, research on sexual fluidity in children remains scarce.

The complexity in terms of orientation labels was also discussed by Blank (2012) and Ward (2015), where the societal hegemony predominates our contemporary Western world. Blank (2012) shows the term "heterosexual" as a relatively new word, originating only in the early 1900s as an attempt to pathologize sexual activity that was not procreative in nature. The work of Foucault (1984) compliments that of Blank (2015), by arguing how, as society advances, sex and sexuality has become a "discourse" rather than an "art", further pathologizing the concept of sexuality and sexual variations. Additionally, Ward (2015) discusses how societal hegemony has constructed heteronormative values which promotes heteroerotic behaviour as an attempt 
at masculinization. Ward's (2015) work is discussed more in the next section as it relates to men's sexual fluidity.

\section{Hetero/Homosexual Binary of Men}

The theme of hetero/homosexual binary of men refers to the imagined dichotomy that exists among men between heterosexuality and homosexuality. Ward (2015) argues such a dichotomy exists, with men choosing to either adopt a heterosexual identity or a homosexual identity (not to confuse with men choosing their orientation, it simply refers to men choosing a selfidentity).

This theme is reflected in much of the literature where men's' selfreported orientation does not necessarily correlate to their sexual activity, with men participating in same-sex behaviours while maintaining a heterosexual identity (Katz-Wise et al., 2016; Kinsey et al., 1948; Ward, 2015). Paradoxically, in the study by Esterline and Galupo (2013), men were more likely than women to encourage same-sex interactions and these men were also more likely to express sexist and homonegative attitudes than those who did not encourage these interactions. These findings reflect the assertions by Ward (2015), who argues that men may promote and/or engage in homosexual behaviour in attempts to display heteronormativity. Ward (2015) demonstrates this through case studies of hazing rituals in fraternities and military institutions where men frequently engage in homoerotic behaviour as a form of initiation into "brotherhood". Furthermore, Ward (2015) finds, in a qualitative study, that heterosexually identified men will seek out other men for homoerotic behaviours (such as mutual masturbation and oral and penetrative sex) in attempts to bond with other heterosexual males. However, it is not just heterosexual men who seek out homosexual sex. Diamond (2013) discusses how many homosexually identified men report engaging in heterosexual intercourse with women. This also brings into question the work by Higgins (2004) who investigated homosexually identified men previously married to women and compared them to those who had never been married to women. The assumptions of Higgins about these men placed them in denial about their own personal identity and unhappy with their situation as it was assumed to be "forced". However, Higgins (2004) found this not to be the case for the majority and showed that these men had been content in their relationships with women.

Drummond, Filiault, Anderson, and Jeffries (2014) conducted a qualitative study on undergraduate college men, finding that $29 \%$ of their participants had engaged in at least kissing with another guy, signifying the growing acceptance of homosexuality/bisexuality. This conclusion builds on the work of Kinsey et al. (1948) who found that up to $37 \%$ of men had engaged in some form of homosexual encounter. 
Brickell (2006) proposes the existence of a hetero/homo binary and presents a detailed account of historic writing on the prevalence of homosexual behaviour among men throughout time. In fact, homosexual behaviour among men has a long history of being a culturally and socially acceptable act among affluent and powerful men. It is only recently that homosexuality and samesex behaviour underwent a form of stigmatization, which Ward (2015) argues is the result of the societal movements towards legitimizing and accepting such behaviour and identities. This further compliments the arguments of Foucault (1984) that as society advances, ideas of sexuality and sex endure further oppression and marginalization.

In her critical review, Fantus (2013) discusses a binary between sex and gender, stating that "Oversimplified definitions have led to instilling feelings of inadequacy and exclusion for those who do not identify as heterosexual, promoting discrimination on the basis of sexual attraction, desire, and love." (p. 101-102). Fantus (2013) further advocates for allowing individuals develop their own narrative and self-identity, recognizing the oppressing nature of labels and language upon an individual and parallels this work to Foucault's discussions about power and oppression.

A final, significant study is a qualitative one, on predominantly heterosexual men engaging in homosexual intercourse (Humphreys, 1970). The author identifies the motivating factors behind these homosexual acts as men simply seeking out sexual gratification without any emotional attachment. These men simply sought physical release and excitement from their perceived monotonous lives and the participants felt that other men provided the most logical and convenient outlet. These results mirror the work of Diamond (2009) who found that homosexual women had sex with men as they felt it was "easier" and more convenient for them.

\section{Discussion}

Research in sexuality and gender issues is still in its early stages, having experienced a moratorium up until the late 1990s and early 2000s, the result of which own to stringent societal, political and legal disapproval and oppression. With the propagation and advocacy for gay rights and the legitimization and legalization of homosexuality/lesbianism, research is finally able to begin to understand the intricacies of human sexuality. This time, scientific inquiry in gender and sexuality has begun to shed light on how little we know about human sexuality. The research by Kinsey and colleagues in the 1940s and 50s and the research by Humphreys in the 1970s pioneered to shake the predominant zeitgeist of the time and forced the public, politicians, law enforcement agencies and clinicians to question their beliefs, question what they knew about sexuality and, most importantly, question the prevailing social 
hegemony of the time. A greater acceptance and more progressive, although incomplete, understanding of human sexuality emerged.

The severe societal disapproval had traditionally lead to a culture of homophobia and, as Anderson (2011) describes it, homohysteria. While we are beginning to develop a culture of acceptance and understanding of those who were once considered sexual "deviants" and "perverts", the inherent repercussions of this culture has hindered our ability to conduct substantive and accurate research. Marcus (2002) presents many first-hand accounts of those gay/lesbians living during the times of great oppression, when homosexuality was considered a crime. He tells stories that are superimposed with stigmatization, fear and sexual repression. While Marcus (2002) details accounts of many pro-gay/lesbian activists being very much involved in research that promoted the advancement of homosexuality, this was not the modus operandi of the majority of the non-conformist population and many individuals with other sexual orientations refused to participate in such research (Marcus, 2002). Societal oppression may have maintained our lack of understanding human sexuality and, furthermore, may have biased the research that potentiated the shift in conceptualizing human sexuality. This may have inadvertently contribute to the conceptualization of human sexuality in a very juvenile, black and white way that is not reflective of true behaviour.

Interestingly, as both Marcus (2002) and Kinsey et al. (1948) outline, while societal hegemony and "norms" influenced people's thoughts, understanding and tempestuous feelings during the times of great oppression, it was insufficient to completely stop non-conforming sexual behaviours. Individuals still acted on their urges, emotions and desires despite their direct contradiction with laws and politics, hegemony, values and norms (Marcus, 2003). This, as Kinsey (1948) argues, suggests a strong biological undertone in sexual behaviour; however, current research remains conflicting in this respect.

It is also important to note the historic research by Hooker (1957) on the adjustment of the male overt homosexual. Some degree of fluidity was reported in her participants, with $10 \%$ of homosexuals reporting having heterosexual intercourse and $10 \%$ of heterosexuals reporting having had homosexual intercourse. These results emerged at a time of severe societal oppression of homosexual behaviour, making it surprising to remark that strict heterosexually identified men risked legal and social repercussions to engage in homosexual activity. This phenomenon, again, supports a biological aspect of sexuality and sexual fluidity.

With the available data on the concept of sexual fluidity, one can see just how dynamic and multifaceted the concept of sexuality and sexual fluidity is. As previously discussed, research has traditionally attempted to dichotomize sexuality into gay and straight, with bisexuals and others being a 
neglected and forgotten orientation (Diamond, 2009). Yet, sexuality does not truly fit this neatly organized conceptualization. While the research outlined may seem conflicting, it presents a preliminary understanding of this existential characteristic of human beings. In her work, Blank (2015) states "... sexuality is a complicated alchemy that mixes biology, gender relations, hierarchy, resources, and power". One should also consider the profound influence of cultural and societal hegemony that is imprinted in the minds of most individuals within the context of Western society. The power of social hegemony is depicted quite impactfully in Marcus' (2002) accounts of those who attempted to "counsel" and "treat" themselves out of homosexuality, as to avoid the behaviour of the "sexual deviant" and "mentally ill".

As with sexuality, sexual fluidity remains poorly understood. Research in biological determinism has yet to illuminate or explain our understanding of either heterosexuals or homosexuals (Diamond, 2009; Ward, 2015) and therefore, does not currently offer explanation for sexual fluidity.

There is a growing need for further understanding of human sexuality. Presently, we do not have the full picture of human experience as it relates to sexual orientation. This aspect remains problematic, considering the growing need for clinicians to effectively counsel, advise and promote the health and well-being of all individuals who may be confused by the variability in attraction they experience. While most succumb to the hegemony that one is biologically determined to be gay or straight, this review highlights the fact that individuals can exhibit variability in their sexual attraction and behaviour. There is no doubt that many may simply maintain one sexual identity for their entire life and that bisexuals and women may be more prone to sexual variations across their lifespan (Diamond, 2009); this is not the rule and variation seems to be a trait with the potential to affect anyone, male or female, fixed-sexual or bisexual.

There is also some concern of stigma. While gay and bisexual individuals already experience profound social stigma and discriminations, Dorsen (2012) and Sabia (2015) found that those who had more of a fluid sexual orientation earned significantly less than those who had a stable heterosexual orientation, with homosexual men earning up to $25 \%$ less than heterosexually identified men and those who were more "fluid" earned even less than those with a stable homosexual identity.

The implications of stigma and its consequences are profound. Individuals sexually fluid are already victims of discrimination and sexism. Awareness is needed so that we may advocate for healthy public policy and greater acceptance of sexual fluidity as a multifaceted phenomenon. 


\section{Limitations}

This integrative review has some notable limitations. The articles in this review were based in Western context and may not be generalizable to all cultures. The review was focused more on adolescent and adult sexual fluidity as opposed to the fluidity of children and seniors; therefore, further research and reviews are needed on these demographics.

\section{Conclusion}

There is still not enough known about human sexuality and variability in human sexuality. More research is needed to further understand this phenomenon across the lifespan and to develop initiatives to help individuals to both understand and accept this trait. More research is also merited on children and seniors, as there is a dearth of available research in these populations. Furthermore, advocacy is needed to ensure equal rights and freedoms without discrimination, both socially and economically.

What is well known and demonstrated is that sexuality is not a fixed trait and is subject to variability for both men and women. There is a clear dualism between sexual behaviour/attraction and love/intimacy that further complicates our understanding of human sexual behaviour. The use of a model or framework, such as the one developed by Diamond (2003), may be useful for guiding our research and understanding of human sexuality issues such as the ones explored in the present review.

\section{References}

1. Anderson, E. (2011). Inclusive Masculinity: The Changing Nature of Masculinities. Abingdon-on-Thames, UK: Routledge.

2. Aramburu AlegrÍa, C. (2013). Relational and sexual fluidity in females partnered with male-to-female transsexual persons. Journal of Psychiatric \& Mental Health Nursing, 20(2), 142-149. https://doi.org/10.1111/j.1365-2850.2011.01863.x

3. Blank, H. (2012). Straight: The Surprisingly Short History of Heterosexuality. Boston, MA: Beacon Press.

4. Brickell, C. (2006). Sexology, the Homo/Hetero Binary, and the Complexities of Male Sexual History. Sexualities, 9(4), 423-447. https://doi.org/10.1177/1363460706068043

5. Coleman-Fountain, E. [b1] (analytic). (2014). Lesbian and gay youth and the question of labels (English). Sexualities (Lond.), 17(7), 802817.

6. Diamond, L. (2013). Lisa Diamond on sexual fluidity of men and women. Retrieved from https://www.youtube.com/watch? $v=m 2$ rTHDOuUBw 
7. Diamond, L. (2009). Sexual Fluidity: Understanding Women's Love and Desire. Cambridge, MA: Harvard University Press.

8. Diamond, L. M. (2003). What does sexual orientation orient? A biobehavioral model distinguishing romantic love and sexual desire (English). Psychol. Rev., 110(1), 173-192.

9. Dorsen, C. (2012). An Integrative Review of Nurse Attitudes Towards Lesbian, Gay, Bisexual, and Transgender Patients. CJNR (Canadian Journal of Nursing Research), 44(3), 18-43.

10. Drummond, M. J. N., Filiault, S. M., Anderson, E., \& Jeffries, D. (2014). Homosocial intimacy among Australian undergraduate men. Journal of Sociology, 1440783313518251. https://doi.org/10.1177/1440783313518251

11. Esterline, K. M., \& Galupo, M. P. (2013). "Drunken Curiosity" and "Gay Chicken": Gender Differences in Same-Sex Performativity. Journal of Bisexuality, 13(1), 106-121. https://doi.org/10.1080/15299716.2013.755732

12. Fantus, S. (2013). The Dichotomy of Sexuality: A NarrativeEpistemological Framework for Social Work Practice and Research. Critical Social Work, 14(2), 99-113.

13. Foucault, M. (1984). The History of Sexuality: An Introduction. Vintage Reissue.

14. Higgins, D. J. (2004). Differences between previously married and never married "gay" men: family background, childhood experiences and current attitudes. Journal of Homosexuality, 48(1), 19-41. https://doi.org/10.1300/J082v48n01_02

15. Humphreys, L. (1970). Tearoom Trade. Duckworth Overlook.

16. Katz-Wise, S. L., \& Hyde, J. S. (2014). Sexual Fluidity and Related Attitudes and Beliefs Among Young Adults with a Same-Gender Orientation. Archives of Sexual Behavior, 44(5), 1459-1470. https://doi.org/10.1007/s10508-014-0420-1

17. Katz-Wise, S. L., Reisner, S. L., Hughto, J. W., \& Keo-Meier, C. L. (2016). Differences in Sexual Orientation Diversity and Sexual Fluidity in Attractions Among Gender Minority Adults in Massachusetts. The Journal of Sex Research, 53(1), 74-84. https://doi.org/10.1080/00224499.2014.1003028

18. Kinsey, A. C., Pomeroy, W. R., \& Martin, C. E. (1948). Sexual Behavior in the Human Male. Indiana University Press.

19. Mock, S. E., \& Eibach, R. P. (2011). Stability and Change in Sexual Orientation Identity Over a 10-Year Period in Adulthood. Archives of Sexual Behavior, 41(3), 641-648. https://doi.org/10.1007/s10508-0119761-1 
20. Notman, M. T. (2002). Changes in sexual orientation and object choice in midlife in women. Psychoanalytic Inquiry, 22(2), 182-195.

21. Ott, M. Q., Corliss, H. L., Wypij, D., Rosario, M., \& Austin, S. B. (2010). Stability and Change in Self-Reported Sexual Orientation Identity in Young People: Application of Mobility Metrics. Archives of Sexual Behavior, 40(3), 519-532. https://doi.org/10.1007/s10508010-9691-3

22. Russell, S. T., Clarke, T. J., \& Clary, J. (2009). Are Teens Post-Gay? Contemporary Adolescents' Sexual Identity Labels (English). J. Youth Adolesc., 38(7), 884-890.

23. Sabia, J. J. (2015). Fluidity in Sexual Identity, Unmeasured Heterogeneity, and the Earnings Effects of Sexual Orientation. Industrial Relations: A Journal of Economy and Society, 54(1), 33-58. https://doi.org/10.1111/irel.12076

24. Ward, J. (2015). Not Gay: Sex Between Straight White Men. New York: New York University Press.

25. Weber, S. (2012). What's wrong with be(com)ing queer? Biological determinism as discursive queer hegemony (English). Sexualities (Lond.), 15(5-6), 679-701.

26. Whittemore, R., \& Knafl, K. (2005). The integrative review: updated methodology. Journal of Advanced Nursing, 52(5), 546-553. https://doi.org/10.1111/j.1365-2648.2005.03621.x 